\title{
Changing income distribution in China
}

\section{Li Shi $^{*}$}

Since the late 1970s, China has undergone transition towards a market economy. In terms of economic growth, China has achieved an impressive record. The average annual growth of GDP per capita was as high as 8.4 per cent during the period 1978 to 1997 . The human development index also indicates an improvement in well-being on the average for the Chinese population (UNDP 1998). During this time, China has become strongly integrated into the world economy. China's exports grew an average of 16.7 per cent per annum over the last two decades. China absorbed US\$205 billion as foreign direct investment during the period 1990-97.

Transition towards a market economy and openness has not been without its problems. An examination of the distribution of wealth in a fast growing economy such as China's provides us with an alternative criterion to evaluate its performance. This examination is primarily based on two similarly constructed household income surveys for 1988 and 1995, respectively. Both surveys have a large sample size drawn from rural and urban China.

\section{Economic transition and income inequality in China}

Since the late 1980 s there have been big changes in sector composition. According to the national accounts, agricultural production grew by 57.6 per cent between 1988 and 1995, while services increased by 73.3 per 
cent. The manufacturing sector grew by 138.5 per cent. In rural China, industry also has grown remarkably, with annual average growth of 24.1 per cent during the period 1985 to 1995 . Rural industry employed 28.6 per cent of the total labour force in rural China in 1995. Results from earlier studies indicate that China is shifting away from subsistence farming (Khan et al. 1992; Zhu 1994).

It is not surprising that the economic reforms have led to a significant change in the ownership structure of Chinese industry. The share of gross output value of industry by state-owned enterprises has been declining, from 57 per cent in 1988 to 26 per cent in 1997, while that of non-public owned enterprises has been increasing, from 7 per cent in 1988 to 36 per cent in 1997 (Table 8.1).

In urban China, employment in the publicly-owned sector increased by only 3.1 per cent from 1988 to 1997 , while employment in the nonpublic sector-private, self-employed, joint-venture, foreign enterprises and so on-increased by an incredible 730.7 per cent and in 1997 accounted for 31.1 per cent of total employment in urban China.

China has been slow to develop labour markets, and labour mobility remained restricted in the mid 1990s. The economic sector is therefore an important institutional variable in determining workers' wages. Workers in a sector with a monopolistic position can share in the rents of their enterprise. Changes in the structure of employment are small but relative wages have undergone greater change (Gustafsson and $\mathrm{Li}$ 1998a). The wage ratio between the sector with the highest, and the sector with the lowest, average income increased from 1.58 in 1988 to 2.26 in 1997 (SSB 1989, 1998).

Another explanation for increased urban income inequality is the ongoing reform of state-owned enterprises. This had two effects. First, state-owned enterprises have been given a greater role in wage determination, creating a tendency for wages to be set higher for better skilled workers. Second, the enterprises have been permitted to lay off redundant workers more freely. Consequently, the number of unemployed workers has increased greatly since 1994. Official statistics show that there was a total of 15 million unemployed by the end of 1998; most of them have not been re-employed.

Economic transition in China has followed a clear regional pattern. Reforms were first institutionalised in the coastal areas. Such areas have since attracted a disproportionately large percentage of foreign investment and economic growth has been most rapid in those parts. 
Table 8.1 Gross output value of industry by ownership in China (billion yuan)

\begin{tabular}{|c|c|c|c|c|c|}
\hline & 1988 & 1991 & 1993 & 1995 & 1997 \\
\hline Gross value & $\begin{array}{r}1822.5 \\
(100)\end{array}$ & $\begin{array}{r}2662.5 \\
(100)\end{array}$ & $\begin{array}{r}4840.2 \\
(100)\end{array}$ & $\begin{array}{r}9189.4 \\
(100)\end{array}$ & $\begin{array}{r}11373.39 \\
(100)\end{array}$ \\
\hline State-owned enterprises & 10.5 .1 & 1495.5 & 2272.5 & 3122.0 & 2902.7 \\
\hline Collective-owned enterprises & $\begin{array}{l}658.8 \\
(36.2)\end{array}$ & $\begin{array}{l}878.3 \\
(33.0)\end{array}$ & $\begin{array}{r}1646.4 \\
(34.0)\end{array}$ & $\begin{array}{r}3362.3 \\
(36.6)\end{array}$ & $\begin{array}{r}4334.7 \\
(38.1)\end{array}$ \\
\hline Township enterprises & $\begin{array}{l}184.7 \\
(10.1)\end{array}$ & $\begin{array}{r}240.1 \\
(9.0)\end{array}$ & $\begin{array}{l}537.4 \\
(11.1)\end{array}$ & $\begin{array}{r}1193.2 \\
(13.0)\end{array}$ & $\begin{array}{l}\text { n.a. } \\
\text { n.a. }\end{array}$ \\
\hline Village enterprises & $\begin{array}{r}170.4 \\
(9.4)\end{array}$ & $\begin{array}{r}234.7 \\
(8.8)\end{array}$ & $\begin{array}{l}516.3 \\
(10.7)\end{array}$ & $\begin{array}{r}1184.7 \\
(12.9)\end{array}$ & $\begin{array}{r}1794.0 \\
(15.8)\end{array}$ \\
\hline Joint enterprises & $\begin{array}{l}43.9 \\
(2.4)\end{array}$ & $\begin{array}{l}56.9 \\
(2.1)\end{array}$ & $\begin{array}{r}132.2 \\
(2.7)\end{array}$ & $\begin{array}{r}213.4 \\
(2.3)\end{array}$ & $\begin{array}{r}466.9 \\
(4.1)\end{array}$ \\
\hline $\begin{array}{l}\text { Individual and private-owned } \\
\text { enterprises }\end{array}$ & $\begin{array}{l}79.1 \\
(4.3)\end{array}$ & $\begin{array}{r}128.7 \\
(4.8)\end{array}$ & $\begin{array}{r}386.1 \\
(8.0)\end{array}$ & $\begin{array}{r}1182.1 \\
(12.9)\end{array}$ & $\begin{array}{r}2037.6 \\
(17.9)\end{array}$ \\
\hline Other ownership & $\begin{array}{l}49.5 \\
(2.7)\end{array}$ & $\begin{array}{r}163.1 \\
(6.1)\end{array}$ & $\begin{array}{l}517.4 \\
(10.7)\end{array}$ & $\begin{array}{r}1523.1 \\
(16.6)\end{array}$ & $\begin{array}{r}2098.2 \\
(18.4)\end{array}$ \\
\hline Shareholding & & & $\begin{array}{r}146.1 \\
(3.0)\end{array}$ & $\begin{array}{r}318.3 \\
(3.5)\end{array}$ & $\begin{array}{r}497.6 \\
(4.4)\end{array}$ \\
\hline Foreign-owned & & & $\begin{array}{r}185.3 \\
(3.8)\end{array}$ & $\begin{array}{r}540.8 \\
(5.9)\end{array}$ & $\begin{array}{r}827.2 \\
(7.3)\end{array}$ \\
\hline $\begin{array}{l}\text { Overseas Chinese from } \\
\text { Hong Kong, Macao, Taiwan }\end{array}$ & & & $\begin{array}{r}176.1 \\
(3.6)\end{array}$ & $\begin{array}{r}556.4 \\
(6.1)\end{array}$ & $\begin{array}{r}612.7 \\
(5.4)\end{array}$ \\
\hline
\end{tabular}

Notes: 1 Gross output values are in current prices; 2 Shares of components are in parentheses (author's calculations).

Sources: State Statistical Bureau, 1994, 1996, 1998. Statistical Yearbook of China, China Statistical Publishing House, Beijing.

The other extreme is the less populated western areas. Inequality in (unweighted) average provincial per capita income has developed with a narrowing of provincial income inequality during the 1980 s, but increasing thereafter (Table 8.2). ${ }^{1}$

Reasons for increased income inequality in China can also be attributed to the tax and social security systems. One of the taxes implemented in rural China is the agricultural tax, levied on the number of household members rather than on income. Subsequently, poor households pay no less tax than rich households. While urban Chinese have much higher incomes on average, only a small proportion of urban workers pay income taxes. Chinese social security is only available to urban workers, and the rural population 
must support themselves. Results indicate that the tax system has caused inequality not only in rural areas, but throughout China (Gustafsson and Li 1998b; Khan and Riskin 1998).

Economic reforms and subsequent changes in lifestyle have had a significant impact on equality of income distribution in China. As a result, income inequality has worsened within rural China and urban China, and between rural and urban areas. Tables 8.3 and Table 8.4 present the results estimated by the State Statistical Bureau (SSB), which indicate the changes in income growth and income inequality in rural and urban China from 1978 to 1997 in terms of the Gini coefficient. The coefficient increased by 55 per cent in rural areas during this period, from 0.212 to 0.329 , while the increase was 82 per cent in urban areas during the same period, from 0.16 to 0.296 . The growth of inequality in rural areas has been different from that in urban areas. There was an augmentation in inequality in rural areas in the early 1980s, triggered by the redistribution of land to individual households. Since then, rural inequality has risen gradually. In contrast, the growth of inequality in urban China is striking, rising in particular years, such as 1984, 1988 and 1994. These increases are related to the implementation of economic reforms (Li et al. 1998).

Meanwhile the income gap between the urban and rural sectors of China has been large. Official statistics indicated an increasing rural-

Table 8.2 Spatial inequality in China: provincial gross national product (GNP) per capita

\begin{tabular}{llllll}
\hline Inequality index & 1980 & 1984 & 1988 & 1995 & 1997 \\
& & & & & \\
Coefficient of variance & 0.951 & 0.753 & 0.675 & 0.665 & 0.686 \\
Gini coefficient & 0.350 & 0.304 & 0.298 & 0.312 & 0.316 \\
Quintile & & & & & \\
1 & 0.1024 & 0.1097 & 0.1061 & 0.0964 & 0.0976 \\
2 & 0.2225 & 0.2371 & 0.2341 & 0.220 & 0.2198 \\
3 & 0.3608 & 0.3851 & 0.3877 & 0.3707 & 0.3696 \\
4 & 0.5228 & 0.5737 & 0.5889 & 0.5892 & 0.5840 \\
5 & 1.0000 & 1.0000 & 1.0000 & 1.0000 & 1.0000 \\
Number of provinces & 30 & 30 & 30 & 30 & 30 \\
& & & & & \\
\hline
\end{tabular}

Source: State Statistical Bureau, various years. Statistical Yearbook of China, China Statistical Publishing House, Beijing. 
urban gap for cash income between 1985 and 1997. Table 8.5 shows the trend of income inequality since the mid 1980s.

Due to increasing inequality of income distribution both within and between rural and urban China, it is not surprising that income inequality in China has been rising since the late 1970s. Results from the two surveys indicated that the Gini coefficient for the whole country increased from 0.382 in 1988 to 0.452 in 1995 (Khan and Riskin 1998).

\section{Data and assumptions}

The data analysed come from two surveys conducted by the project team on China Income Distribution, affiliated with the Institute of Economics, Chinese Academy of Social Sciences (with assistance from the State Statistical Bureau). The first survey of household income in 1988 was conducted in the spring of 1989 and has been analysed by the project team led by Griffin and Zhao (1993) and in some extended studies (Gustafsson and Li 1997, 1998a, 1998b). More detailed descriptions of the survey can be found in Eichen and Zhang (1993) and Khan et al. (1992).

The household income survey for 1995 was conducted during the period January to March 1996. Like the first survey the second had different sample procedures for households in rural and urban areas. Both surveys used large samples from the State Statistical Bureau. Due to budget constraints the sample size for the second survey was reduced by 5000 to 15000 households (with 8000 in the rural and 7000 in the urban sample). The 1995 rural sample covered 109 counties located in 19 provinces while the urban sample covered 11 provinces. ${ }^{2}$ The provinces were chosen with China's geographic differences in mind. ${ }^{3} \mathrm{~A}$ more detailed discussion of the 1995 survey can be found in Khan and Riskin (1998) and Gustafsson and Li (1998b).

The questionnaires were designed by members of the project team. Most questions in the first survey reappeared in the second. The second also contained some new questions. Income-related questions in the urban surveys were posed with the objective of determining household disposable income; households were required to answer questions regarding income-in-kind and the market value of housing subsidies as well as imputed rent of privately-owned houses. In the rural questionnaires, the present value of private houses was asked in order to derive their imputed values by adopting a discount rate. Both the 
Table 8.3 Income growth and income inequality in rural China, 1978-97

\begin{tabular}{lcccc}
\hline \multicolumn{2}{c}{ Gini coefficient } & Real income per capita \\
Year & Level & $\begin{array}{c}\text { Change } \\
(\%)\end{array}$ & $\begin{array}{c}\text { Level } \\
\text { (yuan) }\end{array}$ & $\begin{array}{c}\text { Change } \\
(\%)\end{array}$ \\
& & & & \\
1978 & 0.212 & & 134 & - \\
1979 & 0.237 & 11.8 & $140^{*}$ & 4.5 \\
1980 & $0.238^{*}$ & 0.4 & 146 & 4.3 \\
1981 & 0.239 & 0.4 & 161 & 10.3 \\
1982 & 0.232 & -2.9 & 191 & 18.6 \\
1983 & 0.246 & 6.0 & 210 & 10.0 \\
1984 & 0.258 & 4.9 & 231 & 10.0 \\
Annual growth rate & & & & \\
$1978-84(\%)$ & 3.33 & $n . a$. & 9.50 & $n . a$. \\
1985 & 0.264 & 2.3 & 238 & 3.0 \\
1986 & 0.288 & 9.1 & 240 & 0.8 \\
1987 & 0.292 & 1.4 & 246 & 2.5 \\
1988 & 0.301 & 3.1 & 247 & 0.4 \\
1989 & 0.300 & 0.3 & 228 & -7.7 \\
1990 & 0.310 & 3.3 & 249 & 9.2 \\
Annual growth rate & & & & \\
$1985-90(\%)$ & 3.11 & $n . a$. & 1.26 & $n . a$. \\
1991 & 0.307 & 1.0 & 252 & 1.2 \\
1992 & 0.314 & 2.2 & 266 & 5.6 \\
1993 & 0.320 & 1.9 & 275 & 3.4 \\
Annual growth rate & & & & \\
$1991-93(\%)$ & 1.06 & $n . a$. & 3.37 & $n . a$. \\
1994 & 0.321 & 0.3 & 295 & 7.3 \\
1995 & 0.341 & 6.3 & 325 & 10.2 \\
1996 & 0.323 & -5.3 & 368 & 13.1 \\
1997 & 0.329 & 1.9 & 397 & 7.9 \\
Annual growth rate & & & & \\
$1994-97(\%)$ & 0.7 & $n . a$. & 9.61 & $n . a$. \\
\hline
\end{tabular}

Notes: "Estimated as the mean of figures from the previous year and next year due to omitted value for this year.

Sources: Ping, T., 1995. 'Analysis on income level and inequality of rural households in China', Management World, 2. State Statistical Bureau, various years. Statistical Yearbook of China, China Statistical Publishing House, Beijing. Gini coefficients for years 1994-97 provided by General Team of Rural Household Survey, State Statistical Bureau. 
Table 8.4 Income growth and income inequality in urban China, 1978-97

\begin{tabular}{|c|c|c|c|c|}
\hline \multirow[b]{2}{*}{ Year } & \multicolumn{2}{|c|}{ Gini coefficient } & \multicolumn{2}{|c|}{ Real income per capita } \\
\hline & Level & $\begin{array}{c}\text { Change } \\
(\%)\end{array}$ & $\begin{array}{l}\text { Level } \\
\text { (yuan) }\end{array}$ & $\begin{array}{c}\text { Change } \\
(\%)\end{array}$ \\
\hline 1978 & 0.16 & - & 316 & - \\
\hline 1979 & 0.16 & . & $359^{*}$ & 13.6 \\
\hline 1980 & 0.16 & - & 401 & 11.7 \\
\hline 1981 & 0.15 & -6.3 & 408 & 1.8 \\
\hline 1982 & 0.15 & - & 433 & 6.1 \\
\hline 1983 & 0.15 & - & 451 & 4.2 \\
\hline \multicolumn{5}{|l|}{ Annual growth rate } \\
\hline $1978-83(\%)$ & -1.3 & n.a. & 7.4 & n.a. \\
\hline 1984 & 0.16 & 6.7 & 5.07 & 12.4 \\
\hline 1985 & 0.19 & 18.8 & 510 & 0.6 \\
\hline 1986 & 0.19 & . & 577 & 13.1 \\
\hline 1987 & 0.20 & 5.3 & 586 & 1.6 \\
\hline 1988 & 0.23 & 15.0 & 594 & 1.4 \\
\hline 1989 & 0.23 & 15.0 & 594 & 1.4 \\
\hline \multicolumn{5}{|l|}{ Annual growth rate } \\
\hline $1984-89(\%)$ & 7.4 & n.a. & 2.1 & n.a. \\
\hline 1990 & 0.23 & 0.0 & 625 & 8.7 \\
\hline 1991 & 0.24 & 4.4 & 662 & 5.9 \\
\hline 1992 & 0.25 & 4.2 & 721 & 8.9 \\
\hline 1993 & 0.27 & 8.0 & 794 & 10.1 \\
\hline 1994 & 0.30 & 11.1 & 864 & 8.8 \\
\hline \multicolumn{5}{|l|}{ Annual growth rate } \\
\hline $1990-94(\%)$ & 5.5 & n.a. & 10.9 & n.a. \\
\hline 1995 & 0.282 & -6.0 & 906 & 4.9 \\
\hline 1996 & 0.284 & 0.7 & 940 & 3.8 \\
\hline 1997 & 0.292 & 28 & 972 & 3.4 \\
\hline \multicolumn{5}{|l|}{ Annual growth rate } \\
\hline $1995-97(\%)$ & -0.9 & n.a. & 4.0 & n.a. \\
\hline
\end{tabular}

Sources: Ren, F. and Cheng, $X$, 1996. 'To investigate income differential from income of urban households', Reference of Economic Research, 157 (in Chinese). State Statistical Bureau, various years. Statistical Yearbook of China, China Statistical Publishing House, Beijing. Gini coefficients for years 1994-97 provided by General Team of Urban Household Survey, State Statistical Bureau. 
rural and the urban questionnaires had comprehensive questions regarding household consumption as well as household assets, both financial and physical.

Household disposable income is defined as individual income and household income not attributed to individuals. The former includes earnings, pensions, monetary and in-kind subsidies; the latter, household income from farming, family enterprise and property. Seventy per cent of urban households were still living in public apartments in 1995, paying rents much lower than the market price. Subsequently, housing subsidies for those households were a crucial part of their income. This was calculated as a differential between the respondents' estimate of the market rent and the rents actually paid. ${ }^{4}$ it was also considered important to include imputed rent of privately-owned houses and apartments. For rural China this was done by applying a discount rate of 8 per cent to the present value of the house (as estimated by the respondent).

\section{Table 8.5 Changes in income inequality between rural and urban China, 1985-97}

\begin{tabular}{lcccc}
\hline Year & $\begin{array}{c}\text { Ratio of urban } \\
\text { to rural } \\
\text { (real) income }\end{array}$ & Change & $\begin{array}{c}\text { Ratio of urban } \\
\text { to rural } \\
\text { (nominal) income }\end{array}$ & $\begin{array}{c}\text { Change } \\
(\%)\end{array}$ \\
1985 & 1.72 & - & 1.72 & - \\
1986 & 1.94 & 22 & 1.95 & 13 \\
1987 & 1.91 & -3 & 1.98 & 3 \\
1988 & 1.94 & 3 & 2.05 & 7 \\
1989 & 2.03 & 9 & 2.10 & 5 \\
1990 & 2.02 & -1 & 2.02 & -8 \\
1991 & 2.11 & 9 & 2.18 & 16 \\
1992 & 2.19 & 8 & 2.33 & 15 \\
1993 & 2.32 & 13 & 2.54 & 21 \\
1994 & 2.36 & 4 & 2.60 & 6 \\
1995 & 2.25 & -11 & 2.47 & -13 \\
1996 & 2.05 & -20 & 2.27 & -20 \\
1997 & 2.00 & -5 & 2.23 & -4 \\
\hline
\end{tabular}

Source: State Statistical Bureau, various years. Statistical Yearbook of China, China Statistical Publishing House, Beijing. 
In all tables, reported disposable income for 1995 has been expressed in 1988 prices. This has been done using price indices specific to the rural and urban parts of each province as published by the State Statistical Bureau (1996).

\section{Decomposition analysis of income components}

Changes in inequality as measured by the Gini coefficient can be traced to changes in the size and share of the different income types. The Gini coefficient of individual disposable income is decomposed using

$$
\mathrm{G}=\Sigma \mu_{i} c_{i}
$$

where $\mu_{i}$ is the mean value of an income type $Y_{i}$ as a proportion of individual disposable income, and $C_{i s}$ is the concentration ratio of income type $i$. The concentration ratio is based on the concentration curve which shows cumulated proportions of income type ranked according to disposable income. It is defined as the area between the concentration curve and the diagonal. Unlike the Gini coefficient, which ranges from zero to one, the concentration ratio can take values ranging from -1 to 1 .

Assume first an income type taking positive values. A positive value for the concentration ratio means that the income type contributes positively to total inequality. For taxes, taking negative values, the reverse holds. Each type of income contributes to the Gini coefficient of disposable income by the product of its concentration ratio and its average share of income types.

Many studies argue that non-farming income of rural households has played an important role in increasing the inequality of income distribution in rural China (Khan et al. 1993; Zhu 1994; Khan and Riskin 1998; Li et al. 1998). Using the above approach decomposition analysis of income components was conducted to determine whether non-farming income has increased income inequality in rural China. Rural individual disposable income was decomposed into three components: household production income, individual wage income, and other income including household property income, imputed rental value of privately-owned housing, transfer income and so on (Table 8.6).

Rural inequality in terms of the Gini coefficient increased by nearly 27 per cent between 1988 and 1995, from 0.338 to 0.429 (Table 8.6). 
The concentration ratios of the three income components increased by 1.4 per cent, 4.9 per cent and 24.9 per cent respectively. It is obvious that the increase in inequality of the three income components can only explain a small part of the overall increase in inequality. For the most part it is explained by changes in the share of the three income components. To illustrate this point, we can do two exercises. In one exercise we assume that 1995 disposable income has the same income shares as 1988 disposable income and calculate a simulated Gini coefficient of 0.360 , which is 6.8 per cent higher than the actual coefficient. The difference between the simulated and actual Gini coefficients is due to changes in the distribution of income components. In the other exercise, we assume that each income component in 1995 had the same distribution as that of 1988, and compute a different simulated Gini for rural China, being 0.402. This simulated Gini is 18.9 per cent higher than the actual one. The increase is explained by changes in the share of income components alone. We can conclude that increased inequality in rural China is predominantly due to changes in the share of income components of household income, which reflect rapid but unbalanced growth of industry in rural China.

\section{Table 8.6 Decomposition analysis of income inequality in rural China, 1988 and 1995}

Income and its components

Household
production income
Individual wage
income
Other income
Total income

Ui $(x 100)$

74.21
8.73
17.06
100

Cior $\mathrm{G}$ ei(x100)

$$
\text { ui(x100) } \begin{gathered}
1995 \\
\text { Cior } G \text { ef }(\times 100)
\end{gathered}
$$

$0.282 \quad 61.8$

59.56

0.286

39.7

$0.710 \quad 19.3$

23.62

0.745

41.0

$0.394 \quad 19.9$

0.338100

0.492

$\begin{array}{lll}100 & 0.429 & 100\end{array}$

19.3

Notes: Other income includes household property income, imputed rental value of privately-owned housing and transfer income, and so on. Concentration ratio of other income is calculated by the author. $e$ is the contribution of $f^{\text {th }}$ income to total inequality. It can be formularised as $e_{j}=(U C j) / G$, where $G$ is Gini coefficient of total income.

Sources: Khan, A.R., Griffin, K., Riskin, C. and Zhao, R., 1993. 'Sources of income inequality in post-reform China', China Economic Review, 4:19-35. Li, S., Zhao, R. and Zhang, P., 1998. 'Economic transition and income distribution in China', Economic Research, April:42-51 (in Chinese). 
The results from decomposition analysis indicate a different pattern of change in income inequality for urban China. The urban individual disposable income was decomposed into five components: workers' wage income, workers' non-wage income, income of retirees, income in-kind and other income. Our simulation analysis shows that over 95 per cent of the increase in inequality in urban China is due to changes in the distribution of income components, while a small part is due to changes in share of income components (Table 8.7).

\section{Inequality and personal location}

Many studies have shown that a large part of inequality of income distribution in China is created by regional disparities (Tsui 1993, 1996; Knight and Song 1993; World Bank 1997d; Gustafsson and Li 1998a and 1998b). In this section the population is decomposed into mutually exclusive subgroups according to their location variables. Using the additively decomposable inequality index-the Theil index-inequality in various location subgroups is investigated and their relative contribution to total inequality in China at two points in time is determined.

\section{Table 8.7 Decomposition analysis of income inequality in urban China, 1988 and 1995}

\begin{tabular}{|c|c|c|c|c|c|c|}
\hline $\begin{array}{l}\text { Income and its } \\
\text { components }\end{array}$ & $U i(x 100)$ & $\begin{array}{c}1988 \\
\text { Cior } \mathrm{G}\end{array}$ & $(x 100)$ & $u(x \times 100)$ & $\begin{array}{c}1995 \\
\text { Ci or } G\end{array}$ & $e f(x 100)$ \\
\hline $\begin{array}{l}\text { Worker wage income } \\
\text { Worker non-wage }\end{array}$ & 32.57 & 0.130 & 18.2 & 32.83 & 0.169 & 19.4 \\
\hline income & 25.33 & 0.253 & 27.5 & 24.58 & 0.336 & 28.9 \\
\hline Incomes of retirees & 6.83 & 0.335 & 9.8 & 10.96 & 0.324 & 12.4 \\
\hline Income in-kind & 29.51 & 0.276 & 9.5 & 25.20 & 0.341 & 30.0 \\
\hline Other income & 5.76 & 0.384 & 35.0 & 6.43 & 0.451 & 9.3 \\
\hline Total income & 100 & 0.233 & 100 & 100 & 0.289 & 100 \\
\hline
\end{tabular}

Notes: Income in-kind includes subsidies in-kind for public housing, in-kind income from work units, imputed rental value of privately-owned housing and so on. Other income covers property income, earnings of private owners and self-employees and private transfer income.

Sources: Khan, A.R., Griffin, K., Riskin, C. and Zhao, R., 1993. 'Sources of income inequality in post-reform China', China Economic Review, 4:19-35. Li, S., Zhao, R. and Zhang, P., 1998. 'Economic transition and income distribution in China', Economic Research, April:42-51 (in Chinese). 
The Theil index is defined as

$$
T(y, N)=\sum_{N}^{\sum\left(\frac{y_{i}}{\mu}\right) \log \left(\frac{y_{i}}{\mu}\right)}
$$

and the mean logarithmic deviation (MLD) as

$$
\operatorname{MLD}(\mathrm{y}, \mathrm{N})=\frac{\sum_{i} \log \left(\frac{\mu}{y_{i}}\right)}{N}
$$

where $\mu$ is the mean equivalent income and $N$ the total number of individuals.

Tables 8.8 and 8.9 show the results of decomposition analysis, obtained from work recently produced by Gustafsson and Li (1998b). The entire population was examined by location: rural-urban, eastcentral-west (also called the 'three belts'), and rural-urban and eastcentral-west integration. In analysing the rural-urban divide, Table 8.5 shows the income differential increased by 16 per cent in the period 1988 to 1995 . It can be seen from the decomposition results presented in Table 8.8 that almost two-fifths of inequality in China in 1988 was attributed to differences in mean income between rural and urban China. As the inequality within each sector-especially rural Chinahas increased much faster, total inequality in 1995 is down to onethird, although the rural-urban income gap has widened. ${ }^{5}$ Analysis by Gustafsson and $\mathrm{Li}(1998 \mathrm{~b})$ also illustrates that one-sixth of the increase in inequality in China is due to the increased income gap between rural and urban China.

Table 8.9 shows that within the 'three belts' region, inequality in western China was as significant as in the coastal areas in 1988 but became the worst affected area by 1995 . Mean income in the western part increased at the slowest rate. Therefore the possibility that living standards in the west have deteriorated at the lowest income levels cannot be ruled out. Table 8.8 shows that 7.5 per cent of the inequality in China was attributed to the difference in mean income between the three regions in 1988. This figure rose to 9.3 per cent in 1995. Regional disparity worsened from 1988 to 1995.

Integrating the rural-urban and east-central-west regions yields six groups. Results of the investigations indicate that inequality within the rural-east sector was the greatest both in 1988 and 1995, and increased 
Table 8.8 Decomposition of within-group and between-group inequality in 1988 and 1995 by individual location

\begin{tabular}{|c|c|c|c|c|c|c|c|}
\hline \multirow[b]{2}{*}{$\begin{array}{l}\text { Sample } \\
\text { partition }\end{array}$} & \multicolumn{5}{|c|}{ Mean logarithmic deviation } & \multicolumn{2}{|l|}{ Theil } \\
\hline & Year & $\begin{array}{l}\text { Average } \\
\text { inequality }\end{array}$ & $\begin{array}{l}\text { Within } \\
\text {-group } \\
\text { nequality }\end{array}$ & $\begin{array}{c}\text { Between } \\
\text {-group } \\
\text { inequality }\end{array}$ & $\begin{array}{l}\text { Average } \\
\text { inequality } \\
\text { inequ }\end{array}$ & $\begin{array}{l}\text { Within } \\
\text {-group } \\
\text { Jality ine }\end{array}$ & $\begin{array}{l}\text { Between } \\
\text {-group } \\
\text { quality }\end{array}$ \\
\hline \multicolumn{8}{|l|}{ Rural-urban } \\
\hline & $\begin{array}{l}1988 \\
(\%) \\
1995 \\
(\%)\end{array}$ & $\begin{array}{l}258.31 \\
(100) \\
378.41 \\
(100)\end{array}$ & $\begin{array}{l}159.6 \\
(61.8) \\
255.9 \\
(67.6)\end{array}$ & $\begin{array}{l}98.7 \\
(38.2) \\
122.5 \\
(32.36)\end{array}$ & $\begin{array}{l}253.3 \\
(100) \\
373.14 \\
(100)\end{array}$ & $\begin{array}{l}145.6 \\
(57.5) \\
242.3 \\
(64.9)\end{array}$ & $\begin{array}{l}107.7 \\
(42.5) \\
130.9 \\
(35.1)\end{array}$ \\
\hline \multirow{2}{*}{ Six regions } & $\begin{array}{l}1988 \\
(\%) \\
1995 \\
(\%)\end{array}$ & $\begin{array}{l}258.31 \\
(100) \\
378.41 \\
(100)\end{array}$ & $\begin{array}{l}238.8 \\
(92.5) \\
343.1 \\
(90.7)\end{array}$ & $\begin{array}{l}19.5 \\
(7.5) \\
35.4 \\
(9.3)\end{array}$ & $\begin{array}{l}253.3 \\
(100) \\
373.14 \\
(100)\end{array}$ & $\begin{array}{l}233.6 \\
(92.2) \\
336.9 \\
(90.3)\end{array}$ & $\begin{array}{l}19.7 \\
(7.8) \\
36.2 \\
(9.7)\end{array}$ \\
\hline & $\begin{array}{l}1988 \\
(\%) \\
1995 \\
(\%)\end{array}$ & $\begin{array}{l}258.31 \\
(100) \\
378.41 \\
(100)\end{array}$ & $\begin{array}{l}138.4 \\
(53.6) \\
206.6 \\
(54.6)\end{array}$ & $\begin{array}{l}119.9 \\
(46.4) \\
171.8 \\
(45.4)\end{array}$ & $\begin{array}{l}253.3 \\
(100) \\
373.14 \\
(100)\end{array}$ & $\begin{array}{l}125.8 \\
(49.7) \\
202.7 \\
(54.3)\end{array}$ & $\begin{array}{l}127.5 \\
(50.3) \\
170.4 \\
(45.7)\end{array}$ \\
\hline
\end{tabular}

Notes: 'Income is individual equivalent disposable income. ${ }^{2}$ Subgroups are defined as: rural-urban = rural, urban; 'Three belts' = east, middle, west; Sixregions $=$ rural-east, rural-middle, rural-west, urban-east, urban-middle, urban-west.

Source: Gustafsson, B. and Li, S., 1998a. 'Inequality in China at the end of the $80 \mathrm{~s}$-location aspects and household characteristics', Asian Economic Journal, March:35-63.

significantly between those years, by 68.7 per cent. The rural-west sector experienced the most significant increase in inequality during this time period-73.9 per cent-much greater than that of the rural-central sector. Although the absolute inequality in the three urban sectors was relatively low, the increase was nonetheless remarkable. For instance, inequality increased by 53 per cent in the urban-east sector and by 55 per cent in the urban-central sector. Nearly half of China's inequality can be explained by the difference in mean income between the six sectors. 
Table 8.9 Inequality of sub-group population in 1988 and 1995 by location

\begin{tabular}{|c|c|c|c|c|c|c|c|c|}
\hline & \multicolumn{4}{|c|}{1988} & \multicolumn{4}{|c|}{1995} \\
\hline & $\begin{array}{l}\text { Mean } \\
\text { income } \\
\text { (yuan) }\end{array}$ & $\begin{array}{c}\% \\
\text { of } \\
\text { sample }\end{array}$ & $\begin{array}{c}\text { MLD } \\
(\times 1000)\end{array}$ & $\begin{array}{c}\text { Contrib- } \\
\text { ution } \\
\text { to total } \\
\text { inequality } \\
(\%)\end{array}$ & $\begin{array}{c}\text { Mean } \\
\text { income } \\
\text { (yuan) }\end{array}$ & $\begin{array}{c}\% \\
\text { of } \\
\text { sample }\end{array}$ & $\begin{array}{c}\text { MLD } \\
(\times 1000) \\
(\end{array}$ & $\begin{array}{c}\text { Contrib- } \\
\text { ution } \\
\text { to tolal } \\
\text { inequality } \\
(\%)\end{array}$ \\
\hline $\begin{array}{l}\text { Rural } \\
\text { Urban }\end{array}$ & $\begin{array}{r}822 \\
2131\end{array}$ & $\begin{array}{l}74.1 \\
25.9\end{array}$ & $\begin{array}{r}184.4 \\
88.7\end{array}$ & $\begin{array}{r}52.9 \\
8.9\end{array}$ & $\begin{array}{l}1218 \\
3439\end{array}$ & $\begin{array}{l}71.9 \\
28.1\end{array}$ & $\begin{array}{l}307.4 \\
125.8\end{array}$ & $\begin{array}{r}59.3 \\
9.5\end{array}$ \\
\hline $\begin{array}{l}\text { East } \\
\text { Middle } \\
\text { West }\end{array}$ & $\begin{array}{r}1449 \\
1011 \\
920\end{array}$ & $\begin{array}{l}38.9 \\
38.4 \\
22.6\end{array}$ & $\begin{array}{l}251.9 \\
217.2 \\
252.9\end{array}$ & $\begin{array}{l}37.9 \\
32.3 \\
22.1\end{array}$ & $\begin{array}{l}2508 \\
1486 \\
1423\end{array}$ & $\begin{array}{l}36.4 \\
37.6 \\
26.0\end{array}$ & $\begin{array}{l}354.2 \\
287.1 \\
408.4\end{array}$ & $\begin{array}{l}34.6 \\
28.9 \\
28.5\end{array}$ \\
\hline $\begin{array}{l}\text { Rural-east } \\
\text { Rural-middle } \\
\text { Rural-west } \\
\text { Urban-east } \\
\text { Urban-middle } \\
\text { Urban-west }\end{array}$ & $\begin{array}{r}1044 \\
708 \\
641 \\
2587 \\
1744 \\
2065\end{array}$ & $\begin{array}{r}28.7 \\
27.2 \\
18.2 \\
10.2 \\
11.3 \\
4.4\end{array}$ & $\begin{array}{r}188.1 \\
151.2 \\
134.7 \\
89.8 \\
59.9 \\
64.8\end{array}$ & $\begin{array}{r}20.9 \\
15.9 \\
9.5 \\
3.5 \\
2.6 \\
1.1\end{array}$ & $\begin{array}{r}1786 \\
981 \\
770 \\
4322 \\
2841 \\
3032\end{array}$ & $\begin{array}{r}26.0 \\
27.4 \\
18.5 \\
10.4 \\
10.2 \\
7.5\end{array}$ & $\begin{array}{r}317.4 \\
185.5 \\
233.0 \\
137.7 \\
92.9 \\
84.1\end{array}$ & $\begin{array}{r}22.1 \\
13.6 \\
11.6 \\
3.8 \\
2.5 \\
1.7\end{array}$ \\
\hline
\end{tabular}

Source: Gustafsson, B. and Li, S., 1998a. 'Inequality in China at the end of the 80 s-location aspects and household characteristics', Asian Economic Journal, March:35-63.

\section{Conclusions}

The evidence indicates the rapid growth of household per capita income over the past two decades has been matched by a significant increase in income inequality. The results of our analysis, using both the official and survey data, indicate that the growth of income inequality has been quite general, and has taken place along a number of different dimensions.

Decomposition analysis by income components shows that a large part of the increased inequality in rural China can be explained by changes in the share of income components, resulting from rapid but uneven growth of industry in rural areas. Increased inequality in urban China can be explained by changes in the distribution of income components. 
Location is a significant cause of income inequality. The urban-rural income gap was large by international standards in the 1980s and has continued to widen in the 1990s. However, inequality within urban China and particularly within rural China grew even more rapidly and therefore in the mid 1990s a smaller proportion of total inequality in China was attributed to the rural-urban gap.

The growth of household income differed across regions. Households in the already better-off eastern part of China experienced much larger income growth on average than households living elsewhere, and only a modest increase in inequality among them. In contrast, the mean income in the western part of China has increased at the lowest rate, while inequality there has increased most significantly. Results suggest that low-income groups in the west might even have experienced a decline in income. A larger proportion of Chinese inequality in 1995 can be attributed to the difference of mean income between eastern, central and western China. Combining the rural-urban gap and the eastern-central-western gap accounts for nearly half the total inequality in China.

Increased inequality between rural and urban China and among different regions has resulted from the slow development of the labour market and various restrictions on mobility and employment, particularly of rural workers. Some restrictions result from the policies of various Chinese governments. Therefore, some changes in present policies are needed to narrow rural-urban and regional disparities by allowing the labour force, especially rural workers, to have more freedom to migrate and experience less discrimination in employment. 


\section{Notes}

"The author is grateful for the useful comments from Professor Bob Gregory. The draft chapter was also discussed at the Conference of Openness and Disparities in China, organised by CERDI-IDREC on 22-23 October 1998 in Clermont-Ferrand, France. This work has been financially supported by the Asian Development Bank and Ford Foundation.

${ }^{1}$ The figures may overestimate the real development due to migration. In the Chinese statistics, migrants are usually included in the population of the provinces of origin, not in the province of destination. Moreover migrant remittances are included in GDP for the province of destination, not in the province of origin. However, it is difficult to determine the extent of the inaccuracy.

${ }^{2}$ The provinces in the rural sample were Beijing, Hebei, Shanxi, Liaoning, Jilin, Jiangsu, Zhejiang, Anhui, Jiangxi, Shandong, Henan, Hubei, Hunan, Guangdong, Sichuan, Guizhou, Yunnan, Shaanxi and Gansu. The provinces in the urban sample were Beijing, Shanxi, Liaoning, Jiangsu, Anhui, Henan, Hubei, Guangdong, Sichuan, Yunnan and Gansu.

${ }^{3}$ A striking difference in household income was found between eastern coastal areas and western areas. Liaoning, Jiangsu, Zhejiang, Shandong and Guangdong represent the eastern coastal area; Hebei, Shanxi, Jilin, Anhui, Jiangxi, Henan, Hubei and Hunan the interior areas; and Sichuan, Guizhou, Yunnan, Shanxi and Gansu the western areas. Beijing is a member of the three large provincelevel municipalities.

${ }^{4}$ The question in the urban questionnaire was phrased: 'If you could rent out your house or apartment estimate the monthly rent.'

${ }^{5}$ The rural-urban income gap measured by MLD increased from 0.0987 in 1988 to 0.1225 in 1995 , a rise of 24 per cent. 